\title{
AGROECOLOGICAL POTENTIAL \\ OF LEGUMES IN CONDITIONS \\ OF INTENSIVE AGRICULTURE OF UKRAINE
}

\section{Olexander Tkachuk ${ }^{1}$ \\ Nataliia Telekalo ${ }^{2}$}

DOI: https://doi.org/10.30525/978-9934-26-021-6-33

\begin{abstract}
The ecological significance of leguminous crops grown in modern intensive crop rotation in Ukraine is considered. In particular, the sown areas of common leguminous crops in Ukraine and the level of their productivity have been analyzed. A comparison is made with the acreage of common field crops in Ukraine. The volume of accumulation of by-products in the form of their straw and stubble is calculated. A comparison is made for these indicators with the most widespread grain crops grown in Ukraine. The data on the content of the main nutrients in the by-products of leguminous crops - nitrogen, phosphorus, potassium are given. On the basis of these indicators, a calculation was made of the accumulation of the main nutrients in the soil, which can come with by-products of leguminous crops at their average yield. We also compared the obtained indicators with the input of nitrogen, phosphorus and potassium into the soil with by-products of the most common grain crops. Calculated symbiotic nitrogen fixation by leguminous crops. Based on this, a conclusion was made about the most effective leguminous crops, the cultivation of which in the modern intensive crop rotation of Ukraine will more contribute to the stabilization of the agroecological state of the soil.

It is proved that an increase in the areas of leguminous crops in the intensive crop rotation of Ukraine will have a positive effect on the agroecological state of the soil. In particular, growing beans allows you to get the highest mass of by-products, which can be buried in the soil $-3.5 \mathrm{t} / \mathrm{ha}$. Also, the by-products of beans provide the input into the soil of all mineral
\end{abstract}

\footnotetext{
${ }^{1}$ Doctror of Agricultural Sciences, Associate Professor, Vinnytsia National Agrarian University, Ukraine

${ }^{2}$ Candidate of Agricultural Sciences, Associate Professor, Vinnytsia National Agrarian University, Ukraine

(C) Olexander Tkachuk, Nataliia Telekalo
} 
phosphorus $-12.6 \mathrm{~kg} / \mathrm{ha}$ of all leguminous crops, as well as potassium $16.5 \mathrm{~kg} / \mathrm{ha}$. By-products allow to accumulate more mineral nitrogen in the soil with by-products $-38.4 \mathrm{~kg} / \mathrm{ha}$. Also, soybeans are characterized by a high symbiotic nitrogen-fixing ability among all leguminous crops $120 \mathrm{~kg} / \mathrm{ha}$.

\section{Introduction}

Modernfield crop rotations of Ukraine, involved in commercial cultivation of agricultural crops, occupy an area of about 1994-1900 hectares. Of these, about $70 \%$ of the specified arable land area is occupied by intensive farming technologies used in agricultural enterprises processing leased land.

In Ukraine, such technologies are characterized by the cultivation of a limited number of crops in the rotation, among which winter wheat prevails, which occupies $31 \%$ in the structure of sown areas, sunflower $30 \%$, corn $-23 \%$ in the structure; intensive use of mineral fertilizers, the volumes of which for the cultivation of these crops reach $200-300 \mathrm{~kg} / \mathrm{ha}$ in the active substance of the main nutrients of nitrogen, phosphorus and potassium, in the physical mass of mineral fertilizers reaches $1000 \mathrm{~kg}$ / ha; repeated use of synthetic pesticides, the amount of which during one growing season can be up to 10 times when growing one crop; frequent return to the same field of the cultivated crop can be in one to two years, and for corn - growing in a row for two to three years by a non-optimal alternation of crops in the crop rotation, when for corn and winter wheat, sunflower is the main precursor, and for sunflower - corn. With such hightech conditions for growing crops in Ukraine, unfavorable conditions are formed for the growth and development of plants, which requires a further increase in the use of chemicals - mineral fertilizers and synthetic pesticides.

Considering the lack of organic fertilizers in the modern crop rotation of Ukrainian agriculture, when in 2019 the fertilized area of soil with manure was only 503600 hectares, which is only $2.7 \%$ of the arable land area with an estimated application of organic fertilizers for the entire arable land area of Ukraine $0.5 \mathrm{t} / \mathrm{ha}$ at a scientifically grounded rate of $18.3 \mathrm{t} / \mathrm{ha}$, which could partially stabilize the stability of such agroecosystems, an important problem arises of finding alternative ways to replenish the stock of organic matter in the soil, which will not only improve the agroecological state of 
soils, but will also lead to an increase in the stability of such monotonous agroecosystems to the impact of harmful organisms - pests, diseases and weeds, the number of which has increased dramatically.

In modern conditions of intensive agriculture in Ukraine, an alternative way of replenishing the stock of nutrients and organic matter in the soil is plowing by-products of common crops grown in crop rotation: straw, stalks and stubble of winter wheat, winter rape, corn, sunflower and others. In Ukraine, such an agro-ecological measure has not been used for a long time, since during the existence of the Soviet Union, grain straw, corn and sunflower stalks were used for animal husbandry as feed and bedding. Since the 2000s, a sharp decline in the livestock sector of Ukrainian agriculture has led to the abandonment of crop by-products in the field, followed by their burning. Only since the 2010 s, agricultural enterprises began to grind plant residues and plow them as organic fertilizer. And in such conditions, a part of the by-products of winter wheat, corn, sunflower, winter rape is withdrawn from fields for biofuel production.

However, a more significant factor in increasing the accumulation of nutrients in the soils of agricultural land in Ukraine is the plowing of by-products of leguminous crops, which is characterized by a significantly higher content of nutrients in its chemical composition, symbiotic nitrogen fixation of leguminous crops during their cultivation, however, the agroecological significance of leguminous crops in modern intensive crop rotation in Ukraine is underestimated .

\section{Analysis of recent research and publications}

The use of by-products of legumes, cereals and cereals to increase the yield of subsequent crops in the crop rotation was studied at the National Scientific Center, Institute of Agriculture of the National Academy of Agrarian Sciences of Ukraine V.F. Kaminskiy (2014).

The study of the properties of straw as an organic fertilizer and the peculiarities of its use for fertilizing the soil and increasing the yield of subsequent crops in the crop rotation are covered in the works of the Sumy National Agrarian University and the Scientific Research Institute of Agriculture of the North-East of the National Academy of Agrarian Sciences of Ukraine (Butenko, A.A., 2020), National Research Center Institute of Agrarian Economics (Korchinsky, A.A., 2015). 
The effect of plowing pea straw together with mineral fertilizers on the indicators of the agrochemical composition of gray forest soil, yield and grain quality of winter wheat were studied at the Institute of Agriculture of the Carpathian Region of the National Academy of Agrarian Sciences of Ukraine by scientists Sedilo, G.M., Dubitsky, A.A., Kachmar, O.I., Vavrinovich, A.V., (2018).

The study of the joint use of by-products of plants and green manure was studied at the Research Institute of Agriculture of Polissia of the National Academy of Agrarian Sciences of Ukraine Bovsunovskiy, A.M., 2009. Fertilization of field crops based on the maximum use of local organic resources, in particular, by-products of plant growing of common agricultural crops are covered in the works Kabanchik, V.M., Sobko, M.I. and Radchenko, A.V. in Institute of Agriculture of the North-East of the National Academy of Agrarian Sciences of Ukraine, 2015. All these scientists note the positive effect of the use of by-products of grain and leguminous crops on the indicators of soil fertility and increasing the yield of subsequent crops in the crop rotation.

\section{Literature review}

Traditional leguminous crops of agricultural land in Ukraine during the second half of the twentieth century was sown peas, which occupied at least $10 \%$ of the sown area of each farm. In those days, its straw was used for animal feed, so it was not scattered over the fields. The removal of nutrients from the soil by cultivated crops was compensated by significant amounts of organic fertilizers. The agroecological significance of peas at that time was determined by its symbiotic nitrogen fixation and the optimal characteristics of this crop as a steam predecessor of winter wheat.

At the same time, it is not uncommon for straw to be burned in the fields after harvest. At the same time, 1.5-2 tons of organic matter is irretrievably lost from one hectare, and the soil microflora is also disturbed. This leads to a decrease in soil fertility, which also affects the yield of agricultural crops. And although in Ukraine at the legislative level there is a ban on such burning of plant residues, it is still ignored by many enterprises from year to year.

In the 21 st century, the acreage of peas in Ukraine has sharply decreased, and its agroecological significance has increased significantly. The decrease in the acreage of peas is due to economic and business factors and not too 
high intensification of the technology of its cultivation. At the same time, the sown areas of other, often rare leguminous crops, in particular soybeans, began to grow.

The straw of leguminous crops contains more organic matter than other organic fertilizers, and very valuable components for increasing soil fertility: cellulose, pentose, hemicellulose and lignin, which are carbon energy substrates for soil microorganisms. It is the main building material for soil humus.

Smelling of one ton of straw is equivalent to $3.5-4.0 \mathrm{t} / \mathrm{ha}$ of straw manure in its effect. This indicates that when $0.2-0.4$ tons of legume straw are left in the soil, 0.3-2.6 tons of humus per hectare is formed. In the research of the Institute of Agriculture of the North-East, it was established that the use of straw as fertilizer during the rotation of a 4-field crop rotation contributed to an increase in the humus content by $0.13-0.17 \%$. The calculations show that with its systematic plowing, it is possible to achieve a deficit-free humus balance in soils without additional costs.

On average, $4.2 \mathrm{~kg}$ of nitrogen, $1.7 \mathrm{~kg}$ of phosphorus, $8.3 \mathrm{~kg}$ of potassium, $4.2 \mathrm{~kg}$ of calcium, $0.7 \mathrm{~kg}$ of magnesium, and a number of trace elements are returned to the soil from one ton of straw of grain and leguminous crops. Fertilization with straw increases the availability of phosphorus and potassium in the soil, due to the dissolving action of acidic substances formed during its decomposition. When plowing straw in an amount of 5 t/ha, up to $40 \mathrm{~kg} / \mathrm{ha}$ of potassium and up to $66 \mathrm{~kg} / \mathrm{ha}$ of nitrogen, as the most essential components of mineral nutrition, are returned to the soil annually. Of course, the nutrients bound in the organic matter of the straw will be available to plants only 3-5 years after the decomposition of the straw. But with the systematic introduction of straw, this problem will disappear by itself.

The straw contains all the nutrients necessary for plants, which are easily available to plants after mineralization.

The wide C: $\mathrm{N}$ ratio in grain straw (70-80: 1) affects its decomposition in the soil. Cellulose-freezing microorganisms need nitrogen. When it is deficient in straw, microorganisms consume mineral nitrogen from the soil, that is, the process of nitrogen immobilization is in progress. It has been established that for the normal course of straw decomposition processes, the C: $\mathrm{N}$ ratio should be 20-30: 1 . Therefore, the efficiency of straw fertilization of grain crops increases significantly when combined with 
additional sources of mineral nitrogen. Depending on the crop, which acted as a predecessor, the dose of mineral nitrogen can vary from 3 to $11 \mathrm{~kg}$ requires additional application of mineral nitrogen.

The annual application of straw improves the agrophysical properties of the soil. In particular, for 3-4 years, the number of valuable water-resistant aggregates larger than $0.25 \mathrm{~mm}$ in size increases and the permeability of soil increases.

Straw has a positive effect on the microbiological activity of the soil. The introduction of straw approximately doubles the amount of cellulolytic microflora in comparison with the control, and also leads to an increase in the activity of nitrogen fixation in the soil. The introduction of straw causes an increase in the «breathing» of the soil - the release of carbon dioxide, which is necessary for plants in the process of photosynthesis.

In the process of straw destruction, physiologically active substances are formed, which in low concentrations can positively affect the growth and development of plants.

The straw yield depends on the crop and its yield. The ratio between the main product and straw ranges from 1:0.8 to 1:2.0. Calculations show that the average annual output of straw for grain and leguminous crops in Ukraine's agriculture over the past five years is 56 million tons. Plowing this volume of straw can provide the return to the soil of about 280 thousand tons of nitrogen, 140 thousand tons of phosphorus and 448 thousand tons of potassium. This amount of nutrients is sufficient to obtain an increase in the grain yield of winter wheat in the amount of 3-3.5 million tons.

The largest sources of supply of plant residues in Ukraine in terms of their volumes, based on the sown area, are wheat straw $-30.3 \%$, corn stalks for grain $-17.9 \%$, barley straw $-12.0 \%$, sunflower stalks $-23.8 \%$ and rapeseed $-12.6 \%$. Making the most of plant residues for fertilizing agricultural crops, one can count on their annual application in favorable years of about $5 \mathrm{t} / \mathrm{ha}$, in unfavorable years - up to $3.5 \mathrm{t} / \mathrm{ha}$.

The decomposition of plant residues in the soil is slow and depends on the quality of plowing and weather conditions. It has been established that up to $46 \%$ of straw decomposes in $2.5-4$ months, and up to $80 \%$ in one and a half to two years. For the decomposition of 1 ton of straw in the soil, after 3 months, about $50 \mathrm{~kg}$ of humus is formed, and after 2 years - about $90-100 \mathrm{~kg}$. 
Along with the specified properties of grain by-products, leguminous plants have a number of advantages, which can significantly increase their positive agroecological effect at lower economic costs. The growth of the agroecological value of leguminous crops in crop rotation is determined not only by their accumulation of organic matter with by-products for a more favorable ratio between nitrogen and carbon, but also by symbiotic nitrogen fixation, a taproot system, loosens the soil well, a variety of crops in crop rotation and an improvement in their rotation, after a short the growing season of leguminous crops - additional accumulation of moisture in the soil, cleaning the agroecosystem from pests, diseases and weeds. At the same time, the sown area of leguminous crops in Ukraine was unjustified and did not allow them to fully realize their agroecological potential.

At the same time, the main agroecological emphasis today is made on the traditional during the last years leguminous crops - peas and soybeans, but the sown areas of other leguminous crops, in particular chickpeas, lentils, beans, beans, are beginning to grow on farms. Very little is known about their agroecological significance in crop rotation.

\section{Conditions, objective and methods of research}

The research was carried out on the basis of processing the materials of the State Statistics Service of Ukraine concerning the sown areas and yield levels of leguminous crops in the farms of Ukraine, in particular soybeans, peas, chickpeas, lentils, beans, beans. On the basis of reference data, an assessment was made of the nitrogen-fixing ability of leguminous crops and the volume of accumulation of by-products in the form of their straw. We also used reference data on the content of nutrients in the straw of the studied leguminous crops: nitrogen, phosphorus, potassium. We used calculation methods for calculating the intake of nutrients into the soil. All these indicators were compared with traditional crops grown in intensive crop rotation.

The main objectives of the research were:

1. To analyze the sown area of leguminous crops in Ukraine and their structure;

2. Provide the actual level of productivity of the main leguminous crops grown in Ukraine;

3. Calculate the volume of possible formation of by-products of leguminous crops, which can be buried in the soil; 
4. Give the chemical composition of the by-products of leguminous plants in terms of the content of the main inorganic substances necessary for plants: nitrogen, phosphorus and potassium;

5. Calculate the volume of input into the soil of the main elements of plant nutrition: nitrogen, phosphorus and potassium when plowing plant residues of leguminous crops;

6 . To analyze the volumes of symbiotic nitrogen fixation of leguminous crops grown by intensive technologies in Ukraine;

7. Make a conclusion about leguminous crops that have the most positive agroecological impact on the supply of nutrients to the soil.

\section{Research results}

According to the State Statistics Service in Ukraine, in 2019 the sown area for leguminous crops was 566.0 thousand hectares, which is about $2.8 \%$ of the total sown area in Ukraine and a very low indicator (Figure 1).

According to scientifically grounded calculations, the minimum required sown area of leguminous crops in the structure of sown areas of field plants in Ukraine to stabilize the agroecological state of agroecosystems should be at least $10 \%$ of the arable land. For this, the sowing of leguminous crops

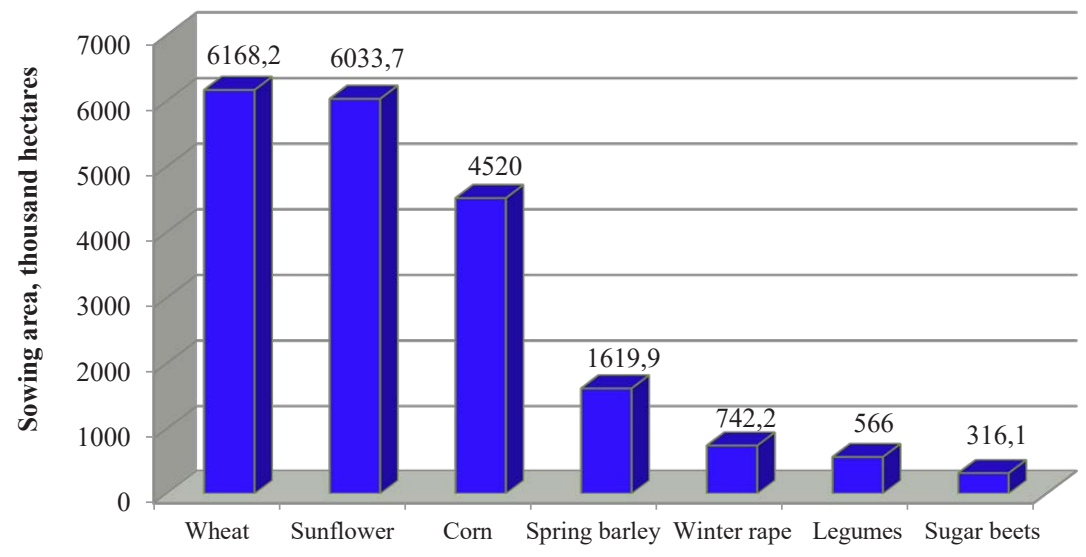

Figure 1. Sown areas of major crops in field crop rotations of Ukraine in 2019 
in Ukraine must be brought to a total area of 1994,190 hectares that is, increased by 3.5 times from existing in 2019.

By the way, in 2015 in Ukraine, according to the State Statistics Service, the sown area of soybeans alone, excluding other leguminous crops, amounted to 1999.8 thousand hectares, which corresponded to the minimum agro-ecological requirements for stabilizing the state of agroecosystems. However, due to the change in climatic conditions, which is due to global warming, there was a significant decrease in the yield of soybeans and since then the sown areas of this crop began to decrease sharply.

The largest sown area among leguminous crops, according to the State Statistics Service in Ukraine in 2019, belonged to peas 347.0 thousand hectares. The sown area of soybeans was 129.8 thousand hectares. The rest of leguminous crops have an insignificant sown area from 42.0 thousand hectares - in beans, up to 3.2 thousand hectares - in legumes (Table 1).

Table 1

Sown areas and yield level of legumes in Ukraine in 2019 (according to the State Statistics Service)

\begin{tabular}{|c|c|c|}
\hline Culture & $\begin{array}{c}\text { Sowing area, } \\
\text { thousand hectares }\end{array}$ & Yield, t/ha \\
\hline Soybeans & 129.8 & 2.29 \\
\hline Peas & 347.0 & 2.28 \\
\hline Chickpeas & 36.0 & 1.40 \\
\hline Lentils & 8.0 & 1.39 \\
\hline Beans & 42.0 & 1.59 \\
\hline Fodder beans & 3.2 & 2.32 \\
\hline Total & 566.0 & - \\
\hline
\end{tabular}

Structurally, the share of peas of all leguminous crops grown in Ukraine is $61.3 \%$, the share of soybeans is $22.9 \%$. Lentils and beans in the structure of sown areas among leguminous crops in Ukraine occupy the smallest share $-1.4 \%$ and $0.6 \%$, respectively (Figure 2 ).

The average yield of leguminous crops, according to the State Statistics Service in Ukraine in 2019, varied within 1.39-2.32 t/ha. It was most found in beans, soybeans, and peas, while the lowest was found in lentils, 


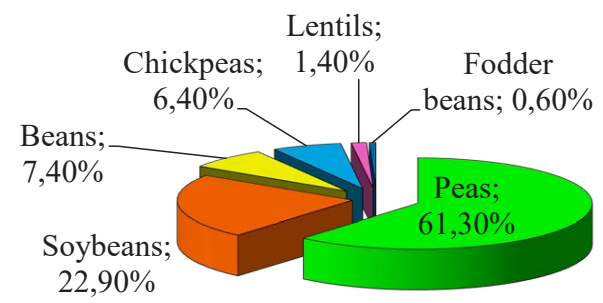

Figure 2. The structure of sown areas of leguminous crops in Ukraine in 2019

chickpeas, and beans. If we take barley, a grain ravine as a reference, the yield of leguminous crops was 0.7-2.4 times less than it.

The ratio of grain to by-products of all leguminous crops is similar and is in the range of 1:(1.2-1.5). Most of the by-products from the mass of seeds are formed by beans, and the least - by lentils (Table 2). In terms of the ratio of grain to by-products, legumes form more by-products than grain crops, and by this indicator they are close to winter rapeseed.

Table 2

\section{Volumes of formation of by-products of legumes in intensive crop rotation}

\begin{tabular}{|c|c|c|}
\hline Culture & $\begin{array}{c}\text { The ratio of grain } \\
\text { to by-products }\end{array}$ & $\begin{array}{c}\text { The average volume } \\
\text { of by-products, } \mathbf{t} / \mathbf{h a}\end{array}$ \\
\hline Soybeans & $1: 1.4$ & 3.2 \\
\hline Peas & $1: 1.4$ & 3.2 \\
\hline Chickpeas & $1: 1.3$ & 1.8 \\
\hline Lentils & $1: 1.2$ & 1.7 \\
\hline Beans & $1: 1.4$ & 2.2 \\
\hline Fodder beans & $1: 1.5$ & 3.5 \\
\hline
\end{tabular}

Taking into account the average level of productivity of leguminous crops in Ukraine, we calculated the formation of vegetative mass of by-products (straw, stems) by them. Most of the by-products can be returned to the soil by beans $-3.5 \mathrm{t} / \mathrm{ha}$, soybeans and peas - by $8.6 \%$ less, beans - by $37.1 \%$, and least of all - chickpeas and lentils $-1.7-1.8 \mathrm{t} / \mathrm{ha}$. In comparison with other field crops of intensive crop rotation, the return 
to the soil of by-products of leguminous crops is lower than from such crops as winter wheat, corn, sunflower, but the same as when forming by-products from spring barley.

The content of the main nutrients in the by-products of all leguminous crops is similar and is: nitrogen $-10.0-12.0 \mathrm{~kg} / \mathrm{t}$, phosphorus $-3.4-3.6 \mathrm{~kg} / \mathrm{t}$, potassium $-4.6-5.0 \mathrm{~kg} / \mathrm{t}$ (Table 3).

Table 3

The content of basic elements in by-products of legumes, $\mathrm{kg} / \mathrm{t}$

\begin{tabular}{|c|c|c|c|}
\hline Culture & $\mathbf{N}$ & $\mathbf{P}$ & $\mathbf{K}$ \\
\hline Soybeans & 12.0 & 3.6 & 5.0 \\
\hline Peas & 10.0 & 3.5 & 4.6 \\
\hline Chickpeas & 10.6 & 3.5 & 4.7 \\
\hline Lentils & 10.8 & 3.4 & 4.6 \\
\hline Beans & 10.6 & 3.5 & 4.7 \\
\hline Fodder beans & 10.6 & 3.6 & 4.7 \\
\hline
\end{tabular}

Soybeans have a somewhat high content of nutrients in by-products, while other crops have approximately the same indicators. In terms of nitrogen content, leguminous crops are dominated by cereals by 2.3-2.7 times, phosphorus by 1.5-1.6 times and are inferior in terms of potassium content.

With the vegetative mass of by-products of leguminous crops, $19.1-38.4 \mathrm{~kg} / \mathrm{ha}$ of mineral nitrogen will come from it. Most of it will be accumulated for growing soybeans and beans, and least of all - for growing chickpeas and lentils. Smelling of soybean by-products ensures that the soil is supplied with almost twice as much mineral nitrogen as it will be supplied by prioritizing plant residues of winter wheat.

Most of the mineral phosphorus will enter the soil when growing beans $-12.6 \mathrm{~kg} / \mathrm{ha}$, as well as soybeans and peas $-11.2-11.5 \mathrm{~kg} / \mathrm{ha}$, which is 1.1-1.3 times more than it will receive into the ground with winter wheat straw. Less mineral phosphorus will enter the soil with lentil by-products $-5.8 \mathrm{~kg} / \mathrm{ha}$.

Potassium input into the soil with the by-product of beans and soybeans will be the largest and will amount to $16.0-16.5 \mathrm{~kg} / \mathrm{ha}$. At the same time, less will be received when growing lentils $-7.8 \mathrm{~kg} / \mathrm{ha}$.

Unlike other agricultural plants, leguminous crops fix symbiotic nitrogen with the help of nodule bacteria and additionally enrich the soil 
with it. Most of all, it is fixed by soybeans $-120 \mathrm{~kg} / \mathrm{ha}$, beans - by $10 \mathrm{~kg} / \mathrm{ha}$ less, peas - by $20 \mathrm{~kg} / \mathrm{ha}$, beans - by $50 \mathrm{~kg} / \mathrm{ha}$, chickpeas - by $40 \mathrm{~kg} / \mathrm{ha}$ and lentils - by $35 \mathrm{~kg} / \mathrm{ha}$ less.

Taking into account the complex effect of growing leguminous crops on the optimization of the agroecological state of the soil, including the conversion of a part of the organic mass of by-products into humus, the accumulation of nutrients nitrogen, phosphorus and potassium from it, as well as the production of biological nitrogen by leguminous crops in symbiosis with nodule bacteria, we calculated the total the positive impact of all leguminous crops on the state of the soil, taking into account all the above factors and is presented in relative units in Figure 3.

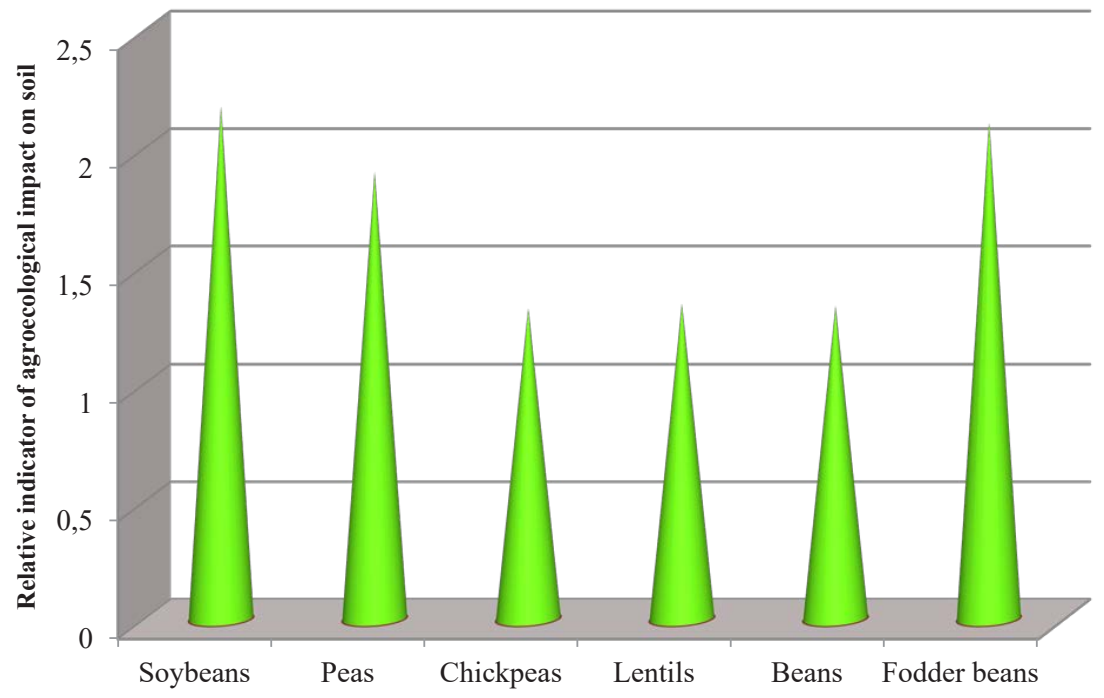

Figure 3. Relative agroecological effect of impact on the soil of growing leguminous crops

The greatest positive impact on the agro-ecological state of the soil is carried out by the cultivation of soybeans with a relative indicator of 2.18 , as well as beans -2.11 . Pea cultivation has a slightly lower rate -1.90 . The rest of leguminous crops - chickpeas, lentils and beans have the lowest relative impact on the soil $-1.32-1.34$. 


\section{Conclusions}

It has been proven that an increase in the area of leguminous crops in an intensive crop rotation will have a positive effect on the agroecological state of the soil. In particular, growing beans allows you to get the highest mass of by-products, which can be buried in the soil $-3.5 \mathrm{t} / \mathrm{ha}$. Also, by-products of beans are characterized by a high content of mineral phosphorus $-3.6 \mathrm{~kg} / \mathrm{t}$, which ensures the supply of all mineral phosphorus to the soil $-12.6 \mathrm{~kg} / \mathrm{ha}$ of all leguminous crops, as well as potassium $-16.5 \mathrm{~kg} / \mathrm{ha}$.

Soybean by-products are characterized by high nitrogen content $-12.0 \mathrm{~kg} / \mathrm{t}$, phosphorus $-3.6 \mathrm{~kg} / \mathrm{t}$ and potassium $-5.0 \mathrm{~kg} / \mathrm{t}$. This makes it possible to accumulate more mineral nitrogen in the soil with by-products after growing soybeans $-38.4 \mathrm{~kg} / \mathrm{ha}$. Also, soybeans are characterized by a high symbiotic nitrogen-fixing ability among all leguminous crops $-120 \mathrm{~kg} / \mathrm{ha}$.

The by-product of leguminous crops has a high nitrogen content by 2.3-2.7 times, phosphorus - 1.5-1.6 times compared to the by-product of grain crops. Also, when plowing soybean by-products into the soil, there will be 2 times more mineral nitrogen and 1.1-1.3 times more phosphorus than when plowing winter wheat by-products.

Among all leguminous crops grown in Ukraine, the greatest positive complex agroecological impact on the soil, taking into account the input of organic matter from by-products, mineral nitrogen, phosphorus and potassium with it and symbiotic nitrogen fixation, will be carried out by the cultivation of soybeans and beans.

\section{References:}

1. Bandura V., Mazur V., Yaroshenko L., Rubanenko O. (2019). Research on sunflower seeds drying process in a monolayer tray vibration dryer based on infrared radiation. INMATEN - Agricultural Engineering, vol. 57, no. 1, pp. 233-242.

2. Didur I., Bakhmat M., Chynchyk O., Pantsyreva H., Telekalo N., Tkachuk O. (2020). Substantiation of agroecological factors on soybean agrophytocenoses by analysis of variance of the Right-Bank ForestSteppe in Ukraine. Ukrainian Journal of Ecology, no. 10(5), pp. 54-61.

3. Didur I., Bakhmat M., Chynchyk O., Pantsyreva H., Telekalo N., Tkachuk O. (2020). Substantiation of agroecological factors on soybean agrophytocenoses by analysis of variance of the Right-Bank ForestSteppe in Ukraine. Ukrainian Journal of Ecology, no. 10(5), pp. 54-61.

4. Didur I., Bakhmat M., Chynchyk O., Pantsyreva H., Telekalo N., Tkachuk O. (2020). Substantiation of agroecological factors on soybean agrophytocenoses by 
analysis of variance of the Right-Bank Forest-Steppe in Ukraine. Ukrainian Journal of Ecology, 10(5), 54-61.

5. Didur I., Pantsyreva H., Telekalo N. (2020). Agroecological rationale of technological methods of growing legumes. The scientific heritage, 52, pp. 3-14.

6. Didur I., Pantsyreva H., Telekalo N. (2020). Agroecological rationale of technological methods of growing legumes. The scientific heritage, 52, pp. 3-14. URL: https://www.ujecology.com/archive.html

7. Kaletnik G.M., Zabolotnyi G.M., Kozlovskyi S.V. (2011). "Innovative models of strategic management economic potential within contemporary economic systems". Actual Problems of Economics, vol. 4(118), pp. 11.

8. Kaletnik, G., \& Lutkovska, S. (2020). Innovative Environmental Strategy for Sustainable Development. European Journal of Sustainable Development, 9(2), 89. https://doi.org/10.14207/ejsd.2020.v9n2p89

9. Kuryata, V.G., Poprotska, I.V., \& Rogach, T.I. (2017). The impact of growth stimulators and retardants on the utilization of reserve lipids by sunflower seedlings. Regulatory Mechanicms in Biosystems, 8(3), 317-322.

10. Mazur O.V., Kolisnyk O.M., Telekalo N.V. (2017). Genotypic differences in varieties of common beans by manufacturability. Collection of scientific works of VNAU «Agriculture and forestry», 7(2), pp. 33-39.

11. Mazur V., Didur I., Myalkovsky R., Pantsyreva H., Telekalo N., Tkach O. (2020). he productivity of intensive pea varieties depending on the seeds treatment and foliar fertilizing under conditions of right-bank forest-steppe Ukraine. Ukrainian Journal of Ecology, no. 10(1), pp. 101-105.

12. Mazur V., Didur I., Myalkovsky R., Pantsyreva H., Telekalo N., Tkach O. (2020). The productivity of intensive pea varieties depending on the seeds treatment and foliar fertilizing under conditions of right-bank forest-steppe Ukraine. Ukrainian Journal of Ecology, no. 10(1), pp. 101-105.

13. Mazur V.A., Didur I.M., Pantsyreva H.V., Telekalo N.V. (2018). Energyeconomic efficiency of growth of grain-crop cultures in conditions of Right-Bank Forest-Steppe of Ukraine. Ukrainian Journal of Ecology, no. 8(4), pp. 26-33.

14. Mazur V.A., Didur I.M., Pantsyreva H.V., Telekalo N.V. (2018). Energyeconomic efficiency of growth of grain-crop cultures in conditions of Right-Bank Forest-Steppe of Ukraine. Ukrainian Journal of Ecology, no. 8(4), pp. 26-33.

15. Mazur V.A., Mazur K.V., Pantsyreva H.V. (2019). Influence of the technological aspects growing on quality composition of seed white lupine (Lupinus albus L.) in the Forest Steppe of Ukraine. Ukrainian Journal of Ecology, vol. 9, pp. 50-55. URL: https://www.ujecology.com/archive.html

16. Mazur V.A., Mazur K.V., Pantsyreva H.V., Alekseev O.O. (2018). Ecological and economic evaluation of varietal resources Lupinus albus L. in Ukraine Ukrainian Journal of Ecology, vol. 8, pp. 148-153.

17. Mazur V.A., Pantsyreva H.V. (2020). «Rid Lupinus L. v Ukraini: henofond, introduktsiia, napriamy doslidzhen ta perspektyvy vykorystannia».VNAU, p. 235.

18. Mazur V.A., Pantsyreva H.V., Didur I.M., Prokopchuk V.M. (2018). Liupyn bilyi. Henetychnyi potentsial ta yoho realizatsiia u silskohospodarske vyrobnytstvo. $V N A U$, p. 231. 
19. Mazur V.A., Pantsyreva H.V., Mazur K.V., Didur I.M. (2019). Influence of the assimilation apparatus and productivity of white lupine plants. Agronomy Research, 17(X), 206-209. URL: https://doi.org/10.15159/AR.19.024

20. Mazur V.A., Pantsyreva H.V., Mazur K.V., Didur I.M. (2019). Influence of the assimilation apparatus and productivity of white lupine plants. Agronomy Research, 17(X), 206-209. URL: https://doi.org/10.15159/AR.19.024

21.Mazur V.A., Pantsyreva H.V., Mazur K.V., Myalkovsky R.O., Alekseev O.O. (2020). Agroecological prospects of using corn hybrids for biogas production. Agronomy Research, 18(1), 177-182.

22. Mazur, V. A., \& Pantsyreva, H. V. (2017). Vplyv tekhnolohichnykh pryiomiv vyroshchuvannia na urozhainist i yakist zerna liupynu biloho $\mathrm{v}$ umovakh Pravoberezhnoho Lisostepu. Silske hospodarstvo i lisivnytstvo, 7, 27-36.

23. Mazur, V.A., Myalkovsky, R.O., Mazur, K.V., Pantsyreva, H.V., Alekseev, O.O. (2019). Influence of the Photosynthetic Productivity and Seed Productivity of White Lupine Plants. Ukrainian Journal of Ecology, 9(4), 665-670.

24. Mazur, V.A., Myalkovsky, R.O., Mazur, K.V., Pantsyreva, H.V., Alekseev, O.O. (2019). Influence of the Photosynthetic Productivity and Seed Productivity of White Lupine Plants. Ukrainian Journal of Ecology, 9(4), 665-670.

25. Mazur, V.A., Prokopchuk, V.M., \& Pantsyreva, G.V. (2018). Primary introduction assessment of decorative species of the lupinus generation in Podillya. Scientific Bulletin of UNFU, 28(7), 40-43. https://doi.org/10.15421/40280708

26. Mazur, V.A., Branitskyi, Y.Y., Pantsyreva, H.V. (2020). Bioenergy and economic efficiency technological methods growing of switchgrass. Ukrainian Journal of Ecology, 10(2), 8-15.

27.Mazur, V.A., Didur, I.M., Pantsyreva, H.V., \& Telekalo, N.V. (2018). Energy-economic efficiency of grain-crop cultures in the conditions of the rightbank Forest-Steppe of Ukraine. Ukrainian J Ecol, 8(4), 26-33.

28. Mazur, V.A., Mazur, K.V., Pantsyreva, H.V., Alekseev, O.O. (2018). Ecological and economic evaluation of varietal resources Lupinus albus L. in Ukraine. Ukrainian Journal of Ecology, 8(4), 148-153.

29. Mazur, V.A., Pantsyreva, H.V., Mazur, K.V. \& Didur, I.M. (2019). Influence of the assimilation apparatus and productivity of white lupine plants. Agronomy research, 17(1), 206-219.

30. Monarkh V.V., Pantsyreva H.V. (2019). Stages of the Environmental Risk Assessment. Ukrainian Journal of Ecology, vol. 9(4), pp. 484-492.

31.Naum Raichesberg (2000). Adolphe Quetelet, His Life and Research Activities. Moscow: Elibron Classics, 98 p.

32. Palamarchuk V., Honcharuk I., Honcharuk T., Telekalo N. (2018). Effect of the elements of corn cultivation technology on bioethanol production under conditions of the right-bank forest-steppe of Ukraine. Ukrainian Journal of Ecology, no. 8(3), pp. 47-53.

33.Palamarchuk V., Telekalo N. (2018). The effect of seed size and seeding depth on the components of maize yield structure. Bulgarian Journal of Agricultural Science, 24(5), pp. 785-792.

34. Pancy reva G.V. (2016). Pol’ova sxozhist` ta vy`zhy`vanist` rosly`n lyupy`nu bilogo zalezhno vid elementiv texnologiyi vy`roshhuvannya u pravoberezhnomu 
Lisostepu Ukrayiny'. Kormy` i kormovy 'robny`cztvo [Field-like behavior and survival of white lupine plants depending on the elements of cultivation technology in the right-bank forest-steppe of Ukraine]. Vinny'cya, 82, 149-152.

35. Pantsyreva H.V., Myalkovsky R.O., Yasinetska I.A., Prokopchuk V.M. (2020). Productivity and economical appraisal of growing raspberry according to substrate for mulching under the conditions of podilia area in Ukraine. Ukrainian Journal of Ecology, vol. 10(1), pp. 210-214.

36. Pantsyreva, H.V. (2016). Doslidzhennia sortovykh resursiv liupynu biloho (Lupinus albus L.) v Ukraini. Silske hospodarstvo i lisivnytstvo, 4, 88-93.

37.Pantsyreva, H.V. (2018). Research of sortal resources of grape species of Paeonia L. in Ukraine. Scientific Bulletin of UNFU, 28(8), 74-78. https://doi.org/10.15421/40280815

38. Polishchuk I.S., Telekalo N.V. (2018). Formation of productivity of spring barley depending on the influence of foliar fertilization in the right-bank forest-steppe conditions. Collection of scientific works of VNAU «Agriculture and forestry», 8, pp. 35-44.

39. Polyvanyi S.V., Golunova L.A., Baiurko N.V., Khodanitska O.O., Shevchuk V.V., Rogach T.I., Tkachuk O.O., Knyazyuk O.V., Zavalnyuk O.L., Shevchuk O.A. (2020). Morphogenesis of mustard white under the action of the antigibberellic preparation chlormequat chloride. Modern Phytomorphology, 14, 101-103.

40. Razanov S.F. Tkachuk O.P., Mazur V.A., Didur I.M. (2018). Effect of bean perennial plants growing on soil heavy metal concentrations. Ukrainian Journal of Ecology, 8(2), 294-300. doi: 10.15421/2018_341

41.Razanov S.F., Tkachuk O.P., Bakhmat O.M., Razanova A.M. (2020). Reducing danger of heavy metals accumulation in winter wheat grain which is grown after leguminous perennial precursor. Ukrainian Journal of Ecology, 10(1), 254-260. doi: 10.15421/2020 40

42. Razanov S.F., Tkachuk O.P., Razanova A.M., Bakhmat M.I., Bakhmat O.M. (2020). Intensity of heavy metal accumulation in plants of Silybum marianum L. in conditions of field rotation. Ukrainian Journal of Ecology, 10(2), 131-136. doi: $10.15421 / 202075$

43. Rohach V.V., Rohach T.I., Kylivnyk A.M., Polyvanyi S.V., Bayurko N.V., Nikitchenko L.O., Tkachuk O.O, Shevchuk O.A., Hudzevych L.S., Levchuk N.V. (2020). The influence of synthetic growth promoters on morphophysiological characteristics and biological productivity of potato culture. Modern Phytomorphology, $14,111-114$.

44. Shevchuk O.A., Kravets O O., Shevchuk V.V., Khodanitska O.O., Tkachuk O.O., Golunova L.A., Polyvanyi S.V., Knyazyuk O.V., Zavalnyuk O.L. (2020). Features of leaf mesostructure organization under plant growth regulators treatment on broad bean plants. Modern Phytomorphology, 14, 104-106.

45. Telekalo N., Melnyk M. (2020). Agroecological substantiation of Medicago sativa cultivation technology. Agronomy Research, 18(X). https://doi.org/10.15159/ AR.20.181

46. Telekalo N., Mordvaniuk M., Shafar H., Matsera O. (2019). Agroecological methods of improving the productivity of niche leguminous crops. Ukrainian Journal of Ecology, no. 9(1), pp. 169-175. 
47. Telekalo N.V. (2018). Agroecological methods of cultivation (pisum sativum) in the forest-steppe conditions of the right bank. Collection of scientific works of VNAU «Agriculture and forestry», 9, pp. 79-88.

48. Telekalo N.V. (2016). Economic evaluation of the efficiency of the technology of growing peas. Collection of scientific works of VNAU «Agriculture and forestry», 4, pp. 63-71.

49. Telekalo N.V. (2017). Influence of technological methods of pea cultivation on soil nitrogen supply. Collection of scientific works of VNAU «Agriculture and forestry», 6(1), pp. 97-102.

50. Telekalo N.V. (2018). The productivity of intensive pea varieties depending on the seeds treatment and foliar fertilizing under conditions of right-bank forest-steppe. Collection of scientific works of VNAU «Agriculture and forestry», 11, pp. 114-122.

51. Telekalo N.V. (2015). Competitiveness of technologies for growing peas in the right-bank forest-steppe. Taurian Scientific Bulletin, 90, pp. 96-101.

52. Telekalo N.V. (2013). Features of formation of grain productivity of peas in the conditions of the right-bank Forest-steppe of Ukraine. Scientific works of the Institute of Bioenergy Crops and Sugar Beets: a collection of scientific works, 17, I, pp. 316-319.

53. Telekalo N.V. (2014). Formation of indicators of individual productivity of grain of intensive varieties of peas. Scientific works of the Institute of Bioenergy Crops and Sugar Beets: a collection of scientific works, 22, pp. 78-83.

54. Telekalo N.V. (2015). Formation of photosynthetic apparatus and pea grain yield in the right-bank forest-steppe. Bulletin of Agrarian Science of the Black Sea Coast, 1(82), pp. 130-136.

55. Telekalo N.V. (2014). Formation of symbiotic and grain productivity of peas in the conditions of the Forest-steppe of the right bank. Taurian Scientific Bulletin, 89 , pp. $72-79$.

56. Telekalo N.V. (2014). Formation of the photosynthetic apparatus and pea grain yield in the conditions of the right-bank Forest-Steppe. Collection of scientific works of VNAU, 6, pp. 41-47.

57. Telekalo N.V. (2014). Influence of inoculation and foliar fertilization on the yield of pea varieties. Legumes and cereals, 1(9), pp. 16-22.

58. Telekalo N.V. (2016). Photosynthetic productivity of peas depending on the impact of pre-sowing seed treatment and foliar fertilization. Collection of scientific works of VNAU «Agriculture and forestry», 3, pp. 65-74.

59. Telekalo N.V. (2019). The effectiveness of bacterial preparations in the cultivation of peas. Collection of scientific works of VNAU "Agriculture and forestry", 14, pp. 127-140.

60. Telekalo N.V. (2019). The influence of a set of technological techniques on the cultivation of peas. Collection of scientific works of VNAU «Agriculture and forestry», 13, pp. 84-93.

61. Telekalo N.V. (2017). The influence of environmental factors on the growth and development of intensive varieties of peas. Collection of scientific works of $V N A U$ «Agriculture and forestry», 5, pp. 241-247. 
62. Telekalo N.V., Blah M.V. (2017). Biological nitrogen as a guarantee of ecological safety of soils. Collection of scientific works of VNAU "Agriculture and forestry», 5, pp. 155-164.

63. Telekalo N.V., Blah M.V. (2017). Influence of elements of cultivation technology on productivity of alfalfa sowing in the conditions of the Forest-steppe of the right bank. Collection of scientific works of VNAU "Agriculture and forestry», 6(2), pp. 35-43.

64. Telekalo N.V., Melnik M.V. (2020). Fodder productivity of alfalfa sowing depending on agroecological methods of cultivation. Agroecological journal, 2, pp. $76-83$.

65. Telekalo N.V., Melnik M.V. (2020). Seed productivity of alfalfa sown depending on the elements of cultivation technology. Scientific reports of NULES of Ukraine, 3(85).

66. Telekalo N.V., Melnik M.V. (2019). Ways to increase the productivity of alfalfa for sowing seeds. Collection of scientific works of VNAU «Agriculture and forestry», vol. 15, pp. 56-63.

67. Telekalo N.V., Melnik M.V. (2020). Improving agroecological methods of growing alfalfa. Collection of scientific works of Vinnytsia National Agrarian University "Agriculture and Forestry», 16, pp. 73-88.

68. Telekalo N.V., Melnyk M.V. (2020). Feed productivity of medicago sativa depending on the elements of growing technology. Colloquium-journal, no. 13(65), pp. $18-20$.

69. Tkachuk O. (2020). Growth and development of leguminous perennial herbs in soil pollution with heavy metals. Sciences of Europe, vol. 3, no. 48, pp. 8-13.

70. Tkachuk O. (2020). Height dynamics of perennial leguminous herbs in the context of soil contamination with heavy metals. Sciences of Europe, vol. 2, no. 49, pp. 7-12.

71. Tymchuk, O. Shkvirko, H. Sakalova, M. Malovanyy, T. Dabizhuk, O. Shevchuk, O. Matviichuk, T. Vasylinych (2020). Wastewater a Source of Nutrients for Crops Growth and Development. Journal of Ecological Engineering, vol. 21, issue 5, pp. 88-96. 